\title{
One variable species or multiple cryptic? Mitochondrial phylogeny of Central and North American Chlosyne lacinia (Lepidoptera: Nymphalidae)
}

\author{
Timothy C. BONEBRAKE ${ }^{1 *}$, Ward B. WATT ${ }^{1}$, Alejandro PEREZ $^{1}$ and CARol L. BOGGS ${ }^{1}$
}

${ }^{1}$ Department of Biology, Stanford University, Stanford CA 94305-5020, USA

\author{
Key words. Phylogeny, genetics, tropical, cryptic species, Melitaeini, Chlosyne, El Salvador
}

\begin{abstract}
Recent efforts to catalogue global biodiversity using genetic techniques have uncovered a number of "cryptic" species within morphologically similar populations that had previously been identified as single species. Chlosyne lacinia (Lepidoptera: Nymphalidae), with a range extending from the Southwest U.S. to South America, is one of the most phenotypically variable and broadly distributed butterfly species in the New World. We sampled populations of C. lacinia in two temperate locations (California and Arizona) and one tropical location (El Salvador) to determine if cryptic species were present at this scale (temperate vs. tropical). We examined mtDNA sequence variation in COI, COII, the intervening tRNA (Leucine-2), 16S, 12S and an additional intervening tRNA (Valine), accounting for approximately $20 \%$ of the mitochondrial genome ( $3479 \mathrm{bp}$ ). Among all C. lacinia individuals, sequence divergence did not exceed 0.0084 compared to a 0.06 estimated divergence between $C$. lacinia and congener $C$. leanira. We also found subclade structure which did not clearly correspond to geography or subspecific designation. Though the mitochondrial phylogeny suggests a complex evolutionary history and biogeography, we demonstrate that one $C$. lacinia species is distributed throughout North and Central America spanning a diverse set of temperate and tropical habitats.
\end{abstract}

\section{INTRODUCTION}

Cryptic species, morphologically indistinguishable or highly similar entities found to be distinct species, have become a recent focus of much ecological and evolutionary study since the advent of PCR and molecular ecological approaches (Bickford et al., 2007). The presence and lack of awareness of cryptic species leads to the potential to vastly underestimate biological diversity (Hebert et al., 2004; Smith, 2006; Burns et al., 2008; Lohman et al., 2010), while also presenting complications for the management of rare and endangered taxa (Schönrogge et al., 2002; Griffiths et al., 2010).

The distribution of cryptic species is especially important across large geographic scales. Species thought to be common and widely distributed are instead frequently found to be multiple cryptic species across a range (Jones $\&$ van Parijs 1993; Colborn et al., 2001; Hebert et al., 2004; Fernandez et al., 2006; Stuart et al., 2006; Murray et al., 2008; Wheat \& Watt 2008; Belyaeva \& Taylor, 2009; Geurgas \& Rodrigues, 2010; McLeod, 2010). Even when cryptic species are revealed, their own particular distributions are important to consider. Multiple sympatric cryptic species throughout a distribution differs greatly in terms of conservation management from allopatric cryptic species with largely disjunct distributions (McBride et al., 2009). However, species exhibiting extensive distributions do not necessarily have cryptic associations. For example, Lohman et al. (2008) showed that Lampides boeticus (Lepidoptera), a butterfly distributed across four continents, did not have any clear cryptic species complexes across its range.
Chlosyne lacinia (Geyer, 1837) is one of the most variable and widespread butterflies in the Americas (Higgins, 1960) and a member of the well-studied Melitaeini butterfly tribe (Harvey, 1991; Ehrlich \& Hanski, 2004; Nymphalidae Systematics Group, 2009). While Chlosyne is represented by species with both Nearctic and Neotropical distributions, Wahlberg \& Zimmerman (2000) present phylogenetic evidence based on mtDNA sequence data to suggest that $C$. lacinia has colonized Central and South America relatively recently and that its sister species are Nearctic in distribution. Could it be that this Neotropcial colonization has led to the rapid radiation of multiple cryptic species? Or alternatively, has one species successfully colonized multiple habitats across large climatic and habitat gradients?

We examined mitochondrial sequence variation in $C$. lacinia among the genes COI, COII, 12S rDNA, 16S rDNA, and two tRNAs following the approach of Wheat \& Watt (2008). In total we sequenced 3,479 bp representing about $20 \%$ of the mitochondrial genome in $14 C$. lacinia butterflies from one tropical population (El Salvador: $\mathrm{n}=6$ ) and two temperate populations (California: $\mathrm{n}=$ 3, Arizona: $n=5$ ). We focused on mitochondrial DNA due to its effectiveness in marking species boundaries in butterfly systematics (Sperling, 2003). Specifically we (i) examined sequence divergence across all C. lacinia individuals and (ii) employed Bayesian and maximum likelihood phylogenetic methods to determine whether or not any distinct mitochondrial lineages were present, in particular in relation to geography (tropical vs. temperate). We used these data to address the question of whether the

\footnotetext{
* Current address: Department of Atmospheric and Oceanic Sciences, UCLA, Los Angeles CA 90095-1565, USA; e-mail: tbone@atmos.ucla.edu
} 
TABLE 1. Locations and IDs of specimens used in this study. Details for Colias meadii and Hipparchia autonoe sequences and specimens can be found in Wheat \& Watt (2008) and Kim et al. (2010) respectively. Details on NW32-2, NW14-4, JM6-8, and JM7-6 can be found at the Nymphalidae Systematics Group (2009) voucher specimen database. Accession numbers for Chlosyne listed in the table are for COI. Additional sequences are also available through Genbank (Accession nos JN584555-JN584629).

\begin{tabular}{|c|c|c|c|c|c|c|c|c|}
\hline Species & ID & Country/State & $\begin{array}{c}\text { County/ } \\
\text { Department }\end{array}$ & Location & Latitude & Longitude & $\begin{array}{c}\text { Collection } \\
\text { Date }\end{array}$ & $\begin{array}{c}\text { Genbank } \\
\text { Accession \# }\end{array}$ \\
\hline Colias meadii & - & U.S./Colorado & - & Baldy Chato & $38 \mathrm{~N}$ & $107 \mathrm{~W}$ & - & $\begin{array}{l}\text { EU583920 } \\
\text { EU583866 }\end{array}$ \\
\hline $\begin{array}{l}\text { Hipparchia } \\
\text { autonoe }\end{array}$ & - & Korea & - & Halla Mt. & $33 \mathrm{~N}$ & $126 \mathrm{E}$ & May 2008 & GQ868707 \\
\hline Chlosyne leanira & - & U.S./Arizona & Cochise & SWRS & $31.9 \mathrm{~N}$ & $109.2 \mathrm{~W}$ & Aug. 2007 & JN584537 \\
\hline \multirow[t]{18}{*}{ Chlosyne lacinia } & 68 & U.S./Arizona & Cochise & Highway 80 & $31.6 \mathrm{~N}$ & $109.1 \mathrm{~W}$ & 21 Aug. 2008 & JN584550 \\
\hline & 72 & U.S./Arizona & Cochise & Highway 181 & $31.9 \mathrm{~N}$ & $109.5 \mathrm{~W}$ & 26 Aug. 2008 & JN584551 \\
\hline & 152 & U.S./Arizona & Cochise & Paradise Cemetery & $31.9 \mathrm{~N}$ & $109.2 \mathrm{~W}$ & 7 Aug. 2008 & JN584548 \\
\hline & 202 & U.S./Arizona & Cochise & Highway 181 & $31.9 \mathrm{~N}$ & $109.5 \mathrm{~W}$ & 26 Aug. 2008 & JN584556 \\
\hline & 263 & U.S./Arizona & Cochise & Paradise Cemetery & $31.9 \mathrm{~N}$ & $109.2 \mathrm{~W}$ & 7 Aug. 2008 & JN584547 \\
\hline & NW32-2 & U.S./Arizona & Cochise & Huachuca Mts. & $31.5 \mathrm{~N}$ & $110.3 \mathrm{~W}$ & 20 May 1998 & AF187779 \\
\hline & 42 & U.S./California & Riverside & Indio $-58^{\text {th }}$ St. & $33.6 \mathrm{~N}$ & $116.2 \mathrm{~W}$ & 23 July 2007 & JN584540 \\
\hline & 128 & U.S./California & Riverside & Indio $-52^{\text {nd }}$ St. & $33.7 \mathrm{~N}$ & $116.2 \mathrm{~W}$ & 23 July 2007 & JN584542 \\
\hline & 241 & U.S./California & Riverside & Indio $-58^{\text {th }}$ St. & $33.6 \mathrm{~N}$ & $116.2 \mathrm{~W}$ & 23 July 2007 & JN584546 \\
\hline & NW14-2 & U.S./Texas & - & South Texas & - & - & 17 Feb. 1999 & JN584554 \\
\hline & 59 & El Salvador & Ahuachapán & Serrano Property & $13.8 \mathrm{~N}$ & $90.0 \mathrm{~W}$ & 13 Dec. 2008 & JN584543 \\
\hline & 198 & El Salvador & Ahuachapán & Serrano Property & $13.8 \mathrm{~N}$ & $90.0 \mathrm{~W}$ & 3 Dec. 2008 & JN584549 \\
\hline & 210 & El Salvador & Ahuachapán & Serrano Property & $13.8 \mathrm{~N}$ & $90.0 \mathrm{~W}$ & 17 Nov. 2008 & JN584545 \\
\hline & 224 & El Salvador & Ahuachapán & Serrano Property & $13.8 \mathrm{~N}$ & $90.0 \mathrm{~W}$ & 8 Nov. 2008 & JN584539 \\
\hline & 255 & El Salvador & Santa Ana & Lake Coatepeque & $13.9 \mathrm{~N}$ & $89.5 \mathrm{~W}$ & 11 Dec. 2008 & JN584544 \\
\hline & 258 & El Salvador & Ahuachapán & Serrano Property & $13.8 \mathrm{~N}$ & $90.0 \mathrm{~W}$ & 28 Nov. 2008 & JN584541 \\
\hline & JM6-8 & Mexico/Morelos & Yautepec & CEPROBI & $18.5 \mathrm{~N}$ & $99.1 \mathrm{~W}$ & 28 Aug. 2007 & JN584552 \\
\hline & JM7-6 & Mexico/Morelos & Yautepec & CEPROBI & $18.5 \mathrm{~N}$ & $99.1 \mathrm{~W}$ & 9 Aug. 2007 & JN584553 \\
\hline
\end{tabular}

extensive distribution of $C$. lacinia is the result of one highly variable butterfly species or if instead it is a complex of multiple cryptic species.

\section{MATERIAL AND METHODS}

\section{Study organism and sites}

Chlosyne lacinia is a morphologically highly variable butterfly with populations distributed from the southern U.S. to northern Argentina (Higgins, 1960; Scott, 1986). Larvae use a variety of host plants within Asteraceae: Heliantheae, and habitats range from desert washes to open tropical secondary growth areas (Neck, 1973; DeVries, 1987; Stewart et al., 2001). While the habits and life histories of temperate $C$. lacinia have been studied in some detail, especially in Texas (e.g. Neck, 1973), much less is known about the ecology of tropical $C$. lacinia (DeVries, 1987). Higgins (1960) cautiously categorized C. lacinia forms into several types or "subspecies" noting that the biological reality behind the types would be difficult to justify given complete gradation among all types and that even single broods are capable of producing multiple types (Edwards, 1893). This has led some (e.g. DeVries, 1987) to ignore completely the subspecific designations.

We collected Chlosyne lacinia adults from populations in California, Arizona and El Salvador (Table 1). Each population corresponded roughly to subspecific designations. Butterflies we collected in California could most accurately be described as C. lacinia adjutrix (Scott, 1986). In Arizona we collected only C. lacinia crocale while the Salvadoran butterflies are best described as C. lacinia lacinia (Higgins, 1960).

\section{Sampling and molecular data collection}

We collected 15 butterflies total (14 C. lacinia and one Chlosyne leanira) from the California, Arizona and El Salvador populations (Table 1). Three of the sampled butterflies (IDs 68,
72 and 202) were collected from the field as larvae and raised to adults before being used in molecular data collection. For outgroups, we used a Chlosyne leanira adult collected from the Southwestern Research Station (SWRS) in Arizona, and extant mitochondrial sequence data from Hipparchia autonoe (Nymphalidae) (Kim et al., 2010) and Colias meadii (Pieridae) (Wheat \& Watt, 2008) as additional outgroups. We also used previously sequenced COI C. lacinia samples available from the Nymphalidae Systematics Group (2009).

We sliced the posterior 3-4 abdominal segments of each butterfly and incubated them overnight in a solution of $180 \mu \mathrm{l}$ phosphate-buffered saline solution (Gibco) and $20 \mu 1$ of Proteinase $\mathrm{K}$ at $55^{\circ} \mathrm{C}$ to improve DNA yield from the dried specimens. We then extracted DNA using a DNeasy kit (Qiagen) following standard protocol. We focused on sequences from COI, COII, the intervening tRNA (Leucine-2), $16 \mathrm{~S}, 12 \mathrm{~S}$ and an additional intervening tRNA (Valine). For amplification and sequencing of these genes, we used existing primers (Caterino \& Sperling, 1999; Chew \& Watt, 2006; Wheat \& Watt, 2008) with some additional $C$. lacinia-specific primers for amplification and sequencing in the case of COII (Table 2). For amplification we performed PCR using Hi-Fi Platinum Taq in a Stratagene Robocycler using cycling conditions of 1 cycle of $3^{\prime} 30^{\prime \prime} 94^{\circ} \mathrm{C}$ melt, $1^{\prime} 30^{\prime \prime} 52^{\circ} \mathrm{C}$ anneal, $3^{\prime} 30^{\prime \prime} 68^{\circ} \mathrm{C}$ extend; 35 cycles of $1^{\prime} 30^{\prime \prime} 94^{\circ} \mathrm{C}$ melt, $1^{\prime} 30^{\prime \prime} 52^{\circ} \mathrm{C}$ anneal, $3^{\prime} 30^{\prime \prime} 68^{\circ} \mathrm{C}$ extend; final extension $10^{\prime} 68^{\circ} \mathrm{C}$. For cycle sequencing we used ABI BigDye 2.0 with the following conditions: 1 cycle of $1{ }^{\prime} 48^{\prime \prime}$ $96^{\circ} \mathrm{C}$ melt, $30^{\prime \prime} 50^{\circ} \mathrm{C}$ anneal, $4^{\prime} 60^{\circ} \mathrm{C}$ extend; 30 cycles of $30^{\prime \prime}$ $96^{\circ} \mathrm{C}$ melt, $30^{\prime \prime} 50^{\circ} \mathrm{C}$ anneal, $4^{\prime} 60^{\circ} \mathrm{C}$ extend; final extension 6 ' $60^{\circ} \mathrm{C}$. We prepped the products for sequencing in an ABI 377 sequencer by cleaning with Sephadex G50, resuspending in 5:1 formamide: EDTA buffer, and loading on membrane combs (Gel Company). 
TABLE 2. Amplification primers (indicated by *) and sequencing primers used for Chlosyne. See Wheat \& Watt (2008) for details. Primers developed specifically for Chlosyne lacinia are indicated by a "cla" in the primer name.

\begin{tabular}{ll}
\hline Primer name & 5'-3' Sequence \\
\hline TY-J-1445-25* & CTCGTTAATAAATTTACAATTTATC \\
C1-N-1945cla & TTGTAGTAATAAAGTAATAGCTCC \\
C1-J-1966cla & AGGAGCTATTAACTTTATTACTACAA \\
C1-N-2480cla & AAATAAATCTAAACTTCATAATA \\
C1-J-2496cla & CCTCTATATTATGAAGTTTAGGA \\
C1-J-2795cla* & GGTATACCACGACGATATTCAGAYTA \\
TL2-N-3020* & TTAAATCCATTACATATATTCTGCC \\
C2-N-3385 & CATAACTTCAATATCATTGATGTCC \\
C2-J-3407cla & TGGTCATCAATGATATTGAAGATA \\
TK-N-3783* & GAGACCATTACTTGCTTTCAGTCATC \\
LR-J-13418N* & AGACATGTTTTTGATAAACAAGTGA \\
LR-N-13880 & TGTATCTTGTGTATCAGAGTTTATTA \\
LR-J-13904 & TAATAAACTCTGATACACAAGATAC \\
TV-N-14114 & GAAAAAGTATTTCATTTACATTG \\
SR-J-14232 & AATGAAAGTGACGGGCAATATG \\
SR-N-14589* & AAACTAGGATTAGATACCCTATTA \\
\hline
\end{tabular}

\section{Data analysis and phylogenetic analysis}

For sequence construction and alignment, we used BioEdit (Hall, 1999) and Mesquite (Maddison \& Maddison, 2010). We aligned sequences manually using as a guide the mitochondrial genomes of $H$. autonoe (Kim et al., 2010) and Drosophila yakuba (Clary \& Wolstenholme, 1985). Following Wheat \& Watt (2008) such that genetic distances were comparable, divergence estimates for the entire genetic dataset and for each gene individually were calculated according to the F84 maximum likelihood algorithm as implemented in DNADIST in Phylip 3.66 (Felsenstein, 2005).
A Bayesian analysis was executed in MrBayes version 3.1.2 (Ronquist \& Huelsenbeck, 2003). We partitioned the sequence data by gene (six partitions - COI, tRNA Leu2, COII, 16S, tRNA Val, 12S) and used jModeltest (Posada, 2008) to determine the optimal nucleotide substitution model based on Akaike Information Criterion (AIC) (Akaike, 1973). Accordingly, we used the $\mathrm{GTR}+\mathrm{G}$ (for $\mathrm{COI}$ and COII), F81 (tRNA Leu2), HKY $+\mathrm{G}$ (16S and tRNA Val) and GTR (12S) models for the Bayesian analysis. We ran four chains (one cold, three hot) for four million generations sampling every 3000 generations. For burn-in, we discarded the first 250 samples. We assessed convergence by verifying that the standard deviation of split fre-

TABLE 3. Divergence estimates as calculated by DNADIST in Phylip between the three outgroups and three representative Chlosyne lacinia individuals from each of the three study populations (AZ - Arizona, CA - California and ES - El Salvador). Divergence estimates are shown by gene (as labeled) and concatenated (in bold).

\begin{tabular}{|c|c|c|c|c|c|c|c|c|c|}
\hline & olias meadii & $\begin{array}{c}\text { Hipparchia } \\
\text { autonoe }\end{array}$ & $\begin{array}{c}\text { Chlosyne } \\
\text { leanira }\end{array}$ & $\begin{array}{l}\text { C. lacinia } \\
\text { (AZ-263) }\end{array}$ & $\begin{array}{l}\text { C. lacinia } \\
\text { (AZ-202) }\end{array}$ & $\begin{array}{l}\text { C. lacinia } \\
\text { (CA-241) }\end{array}$ & $\begin{array}{l}\text { C. lacinia } \\
\text { CA-128) }\end{array}$ & $\begin{array}{l}\text { C. lacinia } \\
\text { (ES-59) }\end{array}$ & \\
\hline $\begin{array}{l}\text { Colias } \\
\text { meadii }\end{array}$ & - & & $\begin{array}{l}0.3123-16 \mathrm{~S} \\
0.0299-12 \mathrm{~S}\end{array}$ & $\begin{array}{l}0.1976-16 \mathrm{~S} \\
0.0296-12 \mathrm{~S}\end{array}$ & $\begin{array}{l}0.1998-16 \mathrm{~S} \\
0.0296-12 \mathrm{~S}\end{array}$ & $\begin{array}{l}0.1981-16 \mathrm{~S} \\
0.0296-12 \mathrm{~S} \\
\end{array}$ & $\begin{array}{l}0.1970-16 \mathrm{~S} \\
0.0296-12 \mathrm{~S}\end{array}$ & $\begin{array}{l}0.1980-16 \mathrm{~S} \\
0.0299-12 \mathrm{~S}\end{array}$ & $\begin{array}{l}0.198 \\
0.029 \\
\end{array}$ \\
\hline $\begin{array}{c}\text { Hipparchia } \\
\text { autonoe }\end{array}$ & $\begin{array}{c}\mathbf{0 . 1 6 6 4} \\
0.1613-\mathrm{COI} \\
0.2418-\mathrm{COII} \\
\end{array}$ & - & $\begin{array}{l}0.3348-16 \mathrm{~S} \\
0.0653-12 \mathrm{~S}\end{array}$ & $\begin{array}{l}0.2143-16 \mathrm{~S} \\
0.0641-12 \mathrm{~S}\end{array}$ & $\begin{array}{l}0.2131-16 \mathrm{~S} \\
0.0641-12 \mathrm{~S}\end{array}$ & $\begin{array}{l}0.2149-16 \mathrm{~S} \\
0.0642-12 \mathrm{~S}\end{array}$ & $\begin{array}{l}0.2151-16 \mathrm{~S} \\
0.0641-12 \mathrm{~S}\end{array}$ & $\begin{array}{l}0.2131-16 \mathrm{~S} \\
0.0644-12 \mathrm{~S}\end{array}$ & $\begin{array}{l}0.216 \\
0.064\end{array}$ \\
\hline $\begin{array}{l}\text { Chlosyne } \\
\text { leanira }\end{array}$ & $\begin{array}{c}\mathbf{0 . 1 6 9 0} \\
0.1670-\mathrm{COI} \\
0.2396-\mathrm{COII} \\
\end{array}$ & $\begin{array}{c}\mathbf{0 . 1 4 9 2} \\
0.1582-\text { COI } \\
0.1981-\text { COII } \\
\end{array}$ & - & & & & & & \\
\hline $\begin{array}{l}\text { C. lacinia } \\
\text { (AZ-263) }\end{array}$ & $\begin{array}{c}\mathbf{0 . 1 6 3 1} \\
0.1667-\text { COI } \\
0.2209-\text { COII } \\
\end{array}$ & $\begin{array}{c}\mathbf{0 . 1 4 3 2} \\
0.1628 \text {-COI } \\
0.1621-\text { COII } \\
\end{array}$ & $\begin{array}{c}\mathbf{0 . 0 5 7 5} \\
0.0622-\mathrm{COI} \\
0.1163-\mathrm{COII} \\
\end{array}$ & - & & & & & $\begin{array}{l}0.0017-16 \mathrm{~S} \\
0.0003-12 \mathrm{~S}\end{array}$ \\
\hline $\begin{array}{l}\text { C. lacinia } \\
\text { (AZ-202) }\end{array}$ & $\begin{array}{c}\mathbf{0 . 1 6 2 0} \\
0.1667-\mathrm{COI} \\
0.2203-\mathrm{COII} \\
\end{array}$ & $\begin{array}{c}\mathbf{0 . 1 4 1 3} \\
0.1644-\text { COI } \\
0.1617-\text { COII } \\
\end{array}$ & $\begin{array}{c}\mathbf{0 . 0 5 6 8} \\
0.0622-\mathrm{COI} \\
0.1158-\mathrm{COII} \\
\end{array}$ & $\begin{array}{c}\mathbf{0 . 0 0 1 4} \\
0.0013-\mathrm{COI} \\
0.0004-\mathrm{COII} \\
\end{array}$ & - & & & & \\
\hline $\begin{array}{l}\text { C. lacinia } \\
\text { (CA-241) }\end{array}$ & $\begin{array}{c}\mathbf{0 . 1 6 3 1} \\
0.1676-\text { COI } \\
0.2204-\text { COII } \\
\end{array}$ & $\begin{array}{c}\mathbf{0 . 1 4 4 1} \\
0.1636-\text { COI } \\
0.1617-\text { COII } \\
\end{array}$ & $\begin{array}{c}\mathbf{0 . 0 5 7 8} \\
0.0679-\text { COI } \\
0.1159-\text { COII } \\
\end{array}$ & $\begin{array}{c}\mathbf{0 . 0 0 0 3} \\
0.0007-\mathrm{COI} \\
0.0000-\mathrm{COII} \\
\end{array}$ & $\begin{array}{c}\mathbf{0 . 0 0 1 7} \\
0.0020-\text { COI } \\
0.0004-\text { COII }\end{array}$ & - & & $\begin{array}{l}0.0017-16 \mathrm{~S} \\
0.0003-12 \mathrm{~S}\end{array}$ & $\begin{array}{l}0.0017-16 \mathrm{~S} \\
0.0003-12 \mathrm{~S}\end{array}$ \\
\hline $\begin{array}{l}\text { C. lacinia } \\
\text { (CA-128) }\end{array}$ & $\begin{array}{c}\mathbf{0 . 1 6 3 0} \\
0.1676-\text { COI } \\
0.2209-\text { COII }\end{array}$ & $\begin{array}{c}\mathbf{0 . 1 4 4 0} \\
0.1636-\text { COI } \\
0.1622-\text { COII }\end{array}$ & $\begin{array}{c}\mathbf{0 . 0 5 7 5} \\
0.0679-\text { COI } \\
0.1163-\text { COII }\end{array}$ & $\begin{array}{c}\mathbf{0 . 0 0 0 6} \\
0.0007-\text { COI } \\
0.0000-\text { COII }\end{array}$ & $\begin{array}{r}\mathbf{0 . 0} \\
0.002 \\
0.0004\end{array}$ & $\begin{array}{r}\mathbf{0 . 0 0} \\
0.0000 \\
0.0000\end{array}$ & - & $\begin{array}{l}0.0021-16 \mathrm{~S} \\
0.0003-12 \mathrm{~S}\end{array}$ & $\begin{array}{l}0.0021-16 \mathrm{~S} \\
0.0003-12 \mathrm{~S}\end{array}$ \\
\hline $\begin{array}{l}\text { C. lacinia } \\
\text { (ES-59) }\end{array}$ & $\begin{array}{c}\mathbf{0 . 1 6 1 5} \\
0.1676-\text { COI } \\
0.2175-\text { COII }\end{array}$ & $\begin{array}{c}\mathbf{0 . 1 4 1 5} \\
0.1620-\text { COI } \\
0.1606-\text { COII }\end{array}$ & $\begin{array}{c}\mathbf{0 . 0 5 8 9} \\
0.0711-\text { COI } \\
0.1159-\text { COII }\end{array}$ & $\begin{array}{c}\mathbf{0 . 0 0 6 7} \\
0.0072-\text { COI } \\
0.0027-\text { COII }\end{array}$ & $\begin{array}{c}\mathbf{0 . 0 0 7 0} \\
0.0085-\mathrm{COI} \\
0.0022-\mathrm{COII}\end{array}$ & $\begin{array}{c}\mathbf{0 . 0 0 6 7} \\
0.0079-\text { COI } \\
0.0022-\text { COII }\end{array}$ & $\begin{array}{c}\mathbf{0 . 0 0 7 3} \\
0.0079-\text { COI } \\
0.0027-\text { COII }\end{array}$ & - & $\begin{array}{l}0.0000-16 \mathrm{~S} \\
0.0000-12 \mathrm{~S}\end{array}$ \\
\hline $\begin{array}{l}\text { C. lacinia } \\
\text { (ES-210) }\end{array}$ & $\begin{array}{c}\mathbf{0 . 1 6 1 7} \\
0.1669-\mathrm{COI} \\
0.2180-\mathrm{COII}\end{array}$ & $\begin{array}{c}\mathbf{0 . 1 4 4 0} \\
0.1622-\text { COI } \\
0.1611-\text { COII }\end{array}$ & $\begin{array}{c}\mathbf{0 . 0 5 8 9} \\
0.0711-\text { COI } \\
0.1159-\text { COII }\end{array}$ & $\begin{array}{c}\mathbf{0 . 0 0 6 8} \\
0.0074-\mathrm{COI} \\
0.0022-\mathrm{COII}\end{array}$ & $\begin{array}{c}\mathbf{0 . 0 0 7 1} \\
0.0087-\text { COI } \\
0.0018 \text {-COII }\end{array}$ & $\begin{array}{c}\mathbf{0 . 0 0 6 8} \\
0.0081-\text { COI } \\
0.0018-\text { COII }\end{array}$ & $\begin{array}{c}\mathbf{0 . 0 0 7 3} \\
0.0081-\mathrm{COI} \\
0.0022-\mathrm{COII}\end{array}$ & $\begin{array}{c}\mathbf{0 . 0 0 0 6} \\
0.0000-\mathrm{COI} \\
0.0004-\mathrm{COII}\end{array}$ & - \\
\hline
\end{tabular}




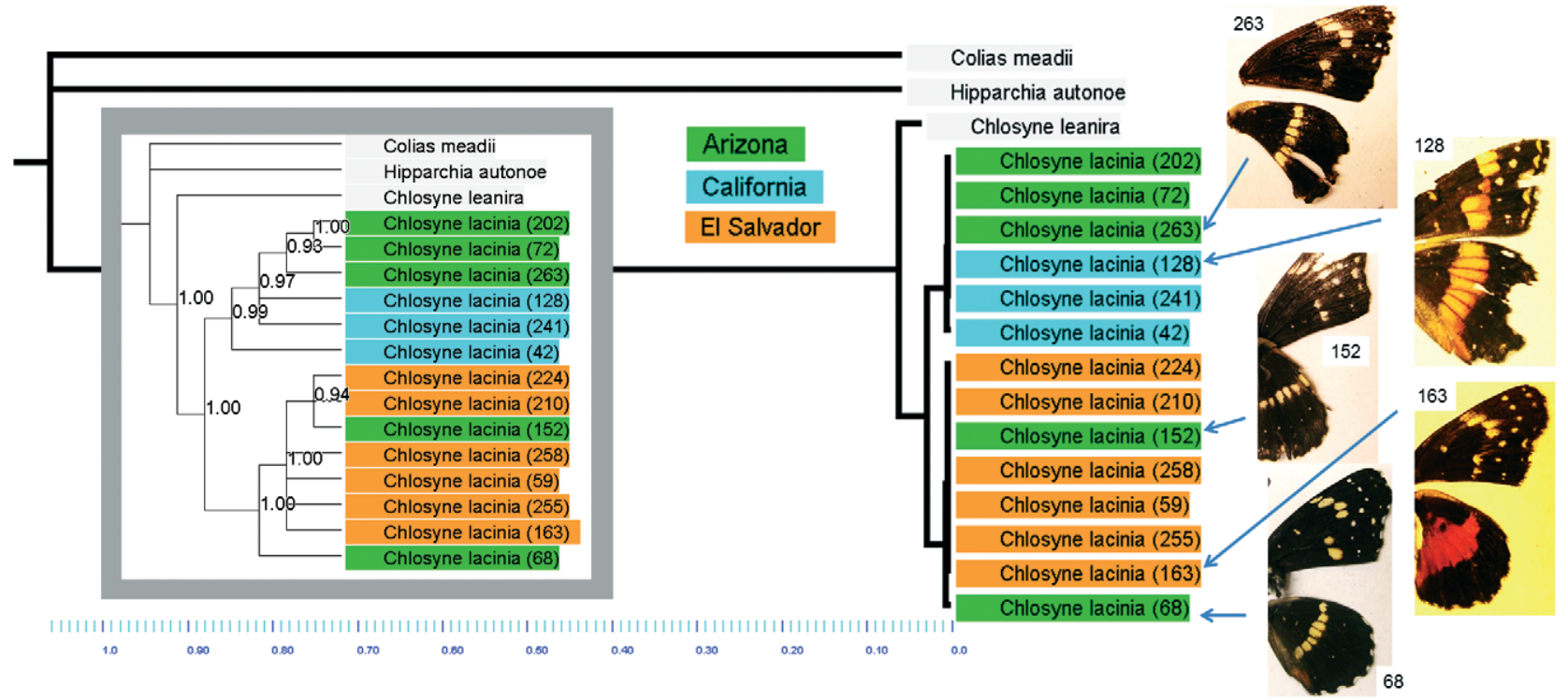

Fig. 1. Bayesian reconstruction of Chlosyne lacinia phylogeny as implemented by MrBayes (Ronquist \& Huelsenbeck, 2003). Inset is a cladogram with equal branch lengths showing posterior probabilities at the nodes. Photos show dorsal wing patterning of key specimens.

quencies was below 0.01 and that the potential scale reduction factor was close to one for each parameter. We also implemented this Bayesian approach for COI separately to assess the phylogenetic relationships of the four C. lacinia samples for which we only have COI sequences. Maximum-likelihood phylogenetic reconstruction was done using PHYML (Guindon \& Gascuel, 2003). We used a GTR substitution model with six categories of gamma distributed rates and performed a bootstrap of 1000 iterations.

\section{RESULTS}

For the concatenated set of $3,479 \mathrm{bp}$, sequence divergence estimated across C. lacinia individuals never exceeded 0.0084 compared to a divergence of 0.06 between $C$. leanira and $C$. lacinia (Table 3). Within populations, Arizona $C$. lacinia exhibited maximum divergence of 0.0070 in Arizona with an estimate of 0.0011 for California and 0.0017 for El Salvador. Divergence estimates by gene are similar relative to the concatenated estimates (Table 3 ).

The Bayesian tree shows that all C. lacinia are closely related to one another and share a recent common ancestor (Fig. 1). However, there is strong support for two distinct mitochondrial lineages within $C$. lacinia. This split does not appear to be related to geography. Individuals 263 and 152 were captured on the same day

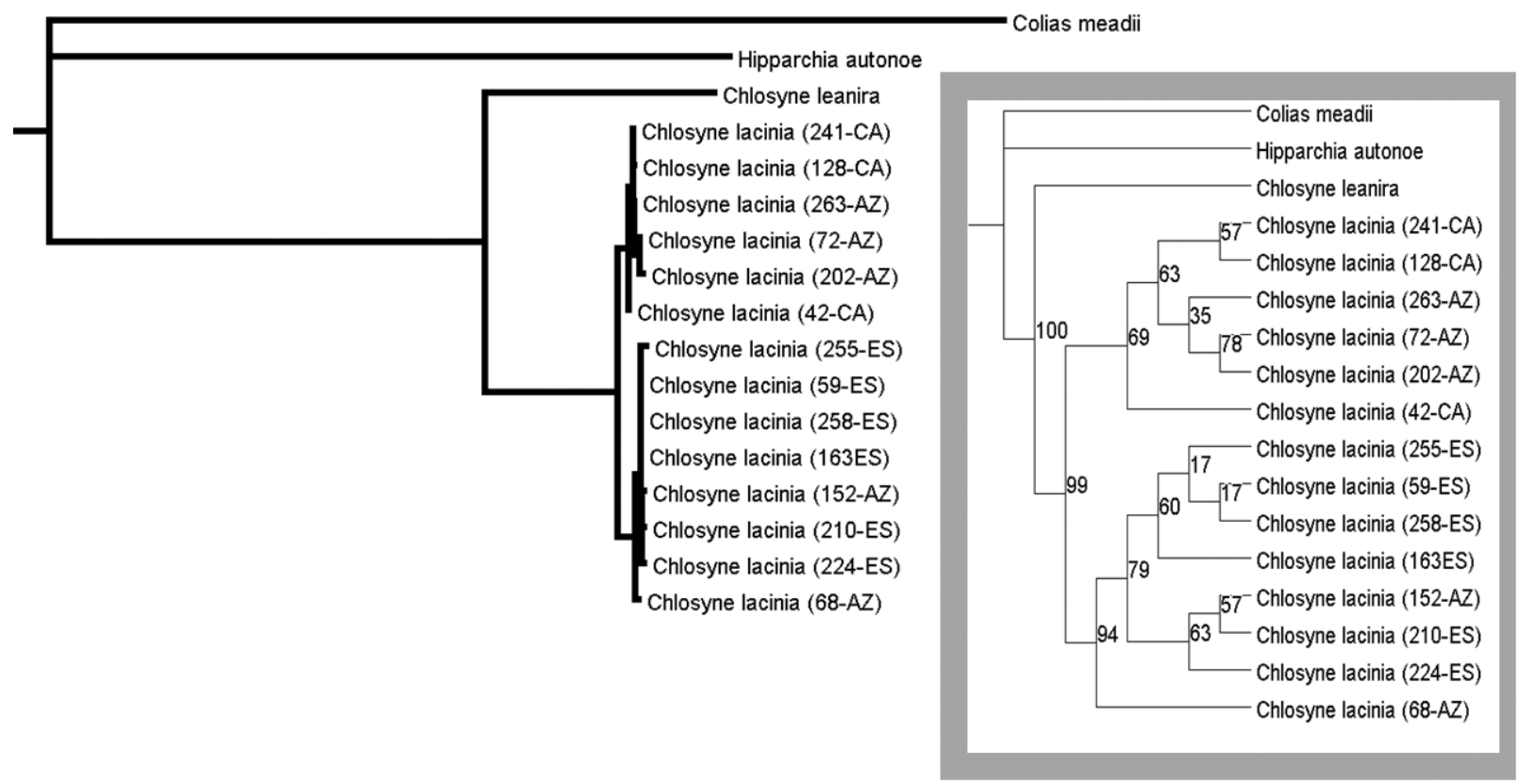

Fig. 2. Maximum-likelihood phylogeny of Chlosyne lacinia from Arizona (AZ), California (CA) and El Salvador (ES) as calculated by PHYML (Guindon \& Gascuel, 2003). Bootstrap percentages from 1000 reiterations are given at each node in the inset. 


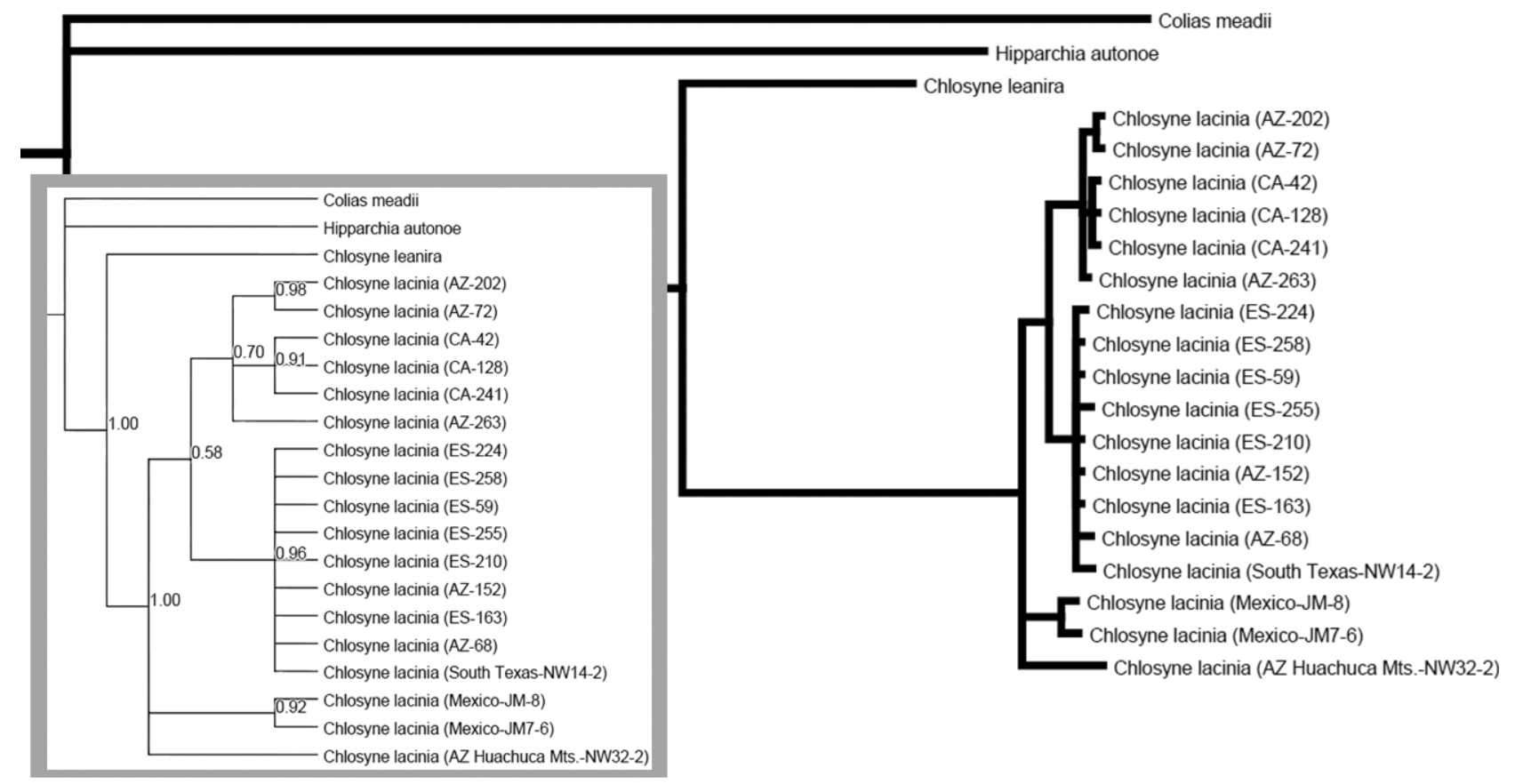

Fig. 3. COI phylogeny of Chlosyne lacinia based on a Bayesian reconstruction in MrBayes (Ronquist \& Huelsenbeck, 2003). Sampling locations include Arizona (AZ), California (CA), El Salvador (ES), South Texas and Mexico with details in Table 1. A cladogram with posterior probabilities displayed at the nodes is inset.

in the same local population (Table 1) but are distinct genetically, although they have similar wing patterning (Fig. 1). The maximum-likelihood phylogeny largely mirrors the Bayesian tree again showing confidence $(94 \%)$ in the splitting of the two C. lacinia clades (Fig. 2). The COI phylogeny shows another grouping of $C$. lacinia representing the Mexican individuals (Fig. 3) but the results largely match the patterns shown by the Bayesian and maximum-likelihood analyses of the concatenated set.

To rule out sequence contamination, we re-extracted, re-amplified and re-sequenced COI from individuals 68 and 152. Consistent with the results from the original data collection, both 68 and 152 have sequences that are much more similar to El Salvador C. lacinia despite their Arizona origin. We found no in-frame stop codons in COI or COII and only one non-synonymous substitution at one polymorphic site in COII and one non-synonymous substitution at a polymorphic site in COI (out of 22 polymorphic sites total throughout COI-COII). This tends to eliminate pseudogene amplification (Brower, 2006; Smith et al., 2007) as a potential alternative explanation of our results.

\section{DISCUSSION AND CONCLUSIONS}

Higgins (1960) accurately noted that for C. lacinia it was "difficult to describe the series in acceptable nomenclature and equally hard to assess the biological significance of the extreme range of variation which is certainly without parallel in the Melitaeinae and hard to match in any other butterfly". Our exploration of mitochondrial sequence diversity across Central and North America showed relatively low levels of genetic divergence across all $C$. lacinia individuals. However, the phylogenetic analysis also uncovered a split in the $C$. lacinia clade with two distinct mitochondrial lineages that appear unrelated to adult subspecific designations or latitude.

Both the Bayesian and maximum-likelihood phylogenetic trees show decisively that the divergence patterns are not related to geography or latitude such that both mitochondrial lineages are present in Arizona. There does not appear to be any correspondence between $C$. lacinia subspecies and subclade structure. The $C$. lacinia individuals we sampled in El Salvador are genetically indistinguishable to two of the individuals we found in Arizona. Therefore, even in the event that each subclade represented a unique species the data show that this split is not due to contemporary geographic separation and that one species is clearly present in both the tropical and temperate environments.

Furthermore, the intraspecific genetic divergence estimates in $C$. lacinia, mostly ranging over about 0.005-0.008, are comparable to intraspecific genetic divergence estimates using sequence data from the same genes (COI, tRNA Leu2, COII, 16S, tRNA Val, 12S) in Colias, as described by Wheat \& Watt (2008). For example, divergence between geographically separated subclades of Colias meadii ranges from 0.0045-0.0054 (Wheat \& Watt, 2008). Also, among closely related species, divergence estimates are frequently between 0.007 and 0.01 (Appendix I in Wheat \& Watt, 2008). The divergence between congener $C$. leanira and C. lacinia $(\sim 0.06)$ also exceeds, by 7 - to 8-fold or more, all divergence estimates among sampled $C$. lacinia. These divergence values are thus consistent with intraspecific estimates in other species. 
The presence of two distinct mitochondrial lineages in Arizona, and potentially a third in Mexico based on COI, suggests a pattern of complex colonization and biogeography. An analogous pattern on a larger scale is described by Gompert et al. (2008) in the Lycaeides butterfly species group. Three distinct mitochondrial lineages (as determined by COI and COII sequences) were found in the group and each of them contained Eurasian and North American haplotypes, suggesting that multiple founding events occurred (Gompert et al., 2008). Introgressive hybridization was also implicated in the radiation of Lycaeides and the complicated genetic structure seen in the group (Gompert et al., 2008, 2010). In the case of $C$. lacinia, it is possible that a colonization of the Neotropics was followed by one or more re-colonizations of North America. Presently however, any hypotheses regarding the cause of the subclade separation would be purely speculative.

While subspecific designation in C. lacinia is based on adult wing pattern, several studies have also demonstrated discrete morphological variation occurring at the larval stage in C. lacinia in North America (Gorodenski, 1969; Neck et al., 1971) and Brazil (Lopes-da-Silva \& Casagrande, 2003). We lack data to address any relationship between larval morph types and mitochondrial sequences though such relationships have proved critical to cryptic species discoveries in other butterfly species (e.g. Hebert et al., 2004).

Comprehensive sampling throughout the extensive distribution of $C$. lacinia would undoubtedly help determine the origins of the complex geographic and morphological variation of $C$. lacinia. One question that naturally arises is whether or not the two mitochondrial lineages are sympatric throughout the $C$. lacinia range or if the mixing observed in Arizona is uncommon. There could also be unsampled subclades or even cryptic species in other parts of its distribution. Yet even within the populations we sampled, a complex evolutionary history is apparent. While we found no clear genetic evidence to justify a delineation of tropical and temperate $C$. lacinia populations, our results also revealed an unexpected genetic substructure within the species.

ACKNOWLEDGMENTS. This research was made possible by the generous support of the U.S. National Science Foundation (OISE-0832204) and the American Museum of Natural History (SWRS Student Support Award) to T.C.B., and of the U.S. National Science Foundation (DEB 0520315, MCB 0846870) to W.B.W. We sincerely thank N. Herrera and the Minesterio de Medio Ambiente y Recursos Naturales de El Salvador for assistance. O. Komar and K. Lara of SalvaNATURA greatly facilitated and supported this research. F. Serrano kindly hosted TCB at his home and workplace in El Salvador for butterfly collection and R. Hernandez worked admirably in finding C. lacinia there. L. Ponisio assisted with butterfly photography. We thank B. Pringle for insightful discussion and N. Wahlberg for additional COI C. lacinia sequences.

\section{REFERENCES}

AKAIKE H. 1973: Information theory as an extension of the maximum likelihood principle. In Petrov B.N. \& Csaki F. (eds): Second International Symposium on Information Theory. Akademiai Kiado, Budapest, pp. 267-281.

Belyaeva M. \& Taylor D.J. 2009: Cryptic species within the Chydorus sphaericus species complex (Crustacea: Cladocera) revealed by molecular markers and sexual stage morphology. Mol. Phylogen. Evol. 50: 534-546.

Bickford D., Lohman D.J., Sodhi N.S., NG P.K., Meier R., Winker K., Ingram K.K. \& Das I. 2007: Cryptic species as a window on diversity and conservation. Trends Ecol. Evol. 22: $148-155$.

BRower A.V.Z. 2006: Problems with DNA barcodes for species delimitation: 'Ten species' of Astraptes fulgerator reassessed (Lepidoptera: Hesperiidae). Syst. Biodivers. 4: 127-132.

Burns J.M., Janzen D.H., Hajibabaei M., Hallwachs W. \& HeBert P.D.N. 2008: DNA barcodes and cryptic species of skipper butterflies in the genus Perichares in Area de Conservacion Guanacaste, Costa Rica. PNAS 105: 6350-6355.

Caterino M.S. \& Sperling F.A.H. 1999: Papilio phylogeny based on mitochondrial cytochrome oxidase I and II genes. Mol. Phylogen. Evol. 11: 122-137.

Chew F.S. \& Watt W.B. 2006: The green-veined white (Pieris napi L.), its Pierine relatives, and the systematics dilemmas of divergent character sets (Lepidoptera, Pieridae). Biol. J. Linn. Soc. 88: 413-435.

Clary D.O. \& Wolstenholme D.R. 1985: The mitochondrial DNA molecule of Drosophila yakuba: nucleotide sequence, gene organization and genetic code. J. Mol. Evol. 22: 252-271.

Colborn J., Crabtree R.E., Shaklee J.B., Pfeiler E. \& Bowen B.W. 2001: The evolutionary enigma of bonefishes (Albula spp.): Cryptic species and ancient separations in a globally distributed shorefish. Evolution 55: 807-820.

DeVries P.J. 1987: The Butterflies of Costa Rica and Their Natural History I. Papilionidae, Pieridae and Nymphalidae. Princeton University Press, Princeton, NJ, 327 pp.

EDWARDS W.H. 1893: Notes on a polymorphic butterfly, Synchloe lacinia, Geyer (in Hub. Zutr.), with description of its prepatory stages. Can. Entomol. 25: 286-291.

EHRLich P.R. \& HANSKI I. 2004: On the Wings of Checkerspots. Oxford University Press, Oxford, $371 \mathrm{pp}$.

FelsensteIn J. 2005: PHYLIP (Phylogeny Inference Package) version 3.6. Distributed by the author. Department of Genome Sciences, University of Washington, Seattle.

Fernandez C.C., Shevock J.R., Glazer A.N. \& Thompson J.N. 2006: Cryptic species within the cosmopolitan desiccation tolerant moss Grimmia laevigata. PNAS 103: 637-642.

Geurgas S.R. \& Rodrigues M.T. 2010: The hidden diversity of Coleodactylus amazonicus (Sphaerodactylinae, Gekkota) revealed by molecular data. Mol. Ecol. 54: 583-593.

Gompert Z., Fordyce J.A., Forister M.L. \& Nice C.C. 2008: Recent colonization and radiation of North American Lycaeides (Plebejus) inferred from mtDNA. Mol. Phylogen. Evol. 48: 481-490.

Gompert Z., Lucas L.K., Fordyce J.A., Forister M.L. \& Nice C.C. 2010: Secondary contact between Lycaeides idas and L. Melissa in the Rocky Mountains: extensive admixture and a patchy hybrid zone. Mol. Ecol. 19: 3171-3192.

GoRODENSKI S.A. 1969: Genetics of three polymorphic larval color forms of Chlosyne lacinia (Lepidoptera, Nymphalidae). Gen. Res. 14: 332-336.

Griffiths A.M., Sims D.W., Cotterell S.P., El Nagar A., Ellis J.R., Lynghammar A., McHugh M., Neat F.C., Pade N.G., Queiroz N., Serra-Pereira B., Rapp T., Wearmouth V.J. \& GENNER M.J. 2010: Molecular markers reveal spatially segregated cryptic species in a critically endangered fish, the 
common skate (Dipturus batis). Proc. R. Soc. Biol. Sci. (B): 277: $1497-1503$.

Guindon S. \& Gascuel O. 2003: A simple, fast, and accurate algorithm to estimate large phylogenies by maximum likelihood. Syst. Biol. 52: 696-704.

Hall T.A. 1999: BioEdit: a user-friendly biological sequence alignment editor and analysis program for Windows 95/98/NT. Nucleic Acids. Symp. Ser. 41: 95-98. Software distributed at http://www.mbio.ncsu.edu/BioEdit/bioedit.html

Harvey D.J. 1991: Higher classification of the Nymphalidae. Appendix B. In Nijhout H.F.: The Development and Evolution of Butterfly wing Patterns. Smithsonian Institution Press, Washington D.C., pp. 255-273.

Hebert P.D.N., Penton E.H., Burns J.M., Janzen D.H. \& HallWACHS W. 2004: Ten species in one: DNA barcoding reveals cryptic species in the neotropical skipper butterfly Astraptes fulgerator. PNAS 101: 14812-14817.

Higgins L.G. 1960: A revision of the melitaeine genus Chlosyne and allied species (Lepidoptera: Nymphalinae). Trans. $R$. Entomol. Soc. Lond. 112: 381-465.

Jones G. \& van PariJs S.M. 1993: Bimodal echolocation in pipistrelle bats: are cryptic species present? Proc. R. Soc. Lond. (B) 251: 119-125.

Kim M.J., Wan X., Kim K.-G., Hwang J.S. \& Kim I. 2010: Complete nucleotide sequence and organization of the mitogenome of endangered Eumenis autonoe (Lepidoptera: Nymphalidae). Afr. J. Biotechnol. 9: 735-754.

Lohman D.J., Peggie D., Pierce N.E. \& Meier R. 2008: Phylogeography and genetic diversity of a widespread Old World butterfly, Lampides boeticus (Lepidoptera: Lycaenidae). BMC Evol. Biol. 8: 301

Lohman D.J., Ingram K.K., Prawiradilaga D.M., Winker K., Sheldon F.H., Moyle R.G., NG P.K.L., Ong P.S., Wang L.K., Braile T.M., Astuti D. \& Meiera R. 2010: Cryptic genetic diversity in "widespread" Southeast Asian bird species suggests that Philippine avian endemism is gravely underestimated. Biol. Conserv. 143: 1885-1890.

Lopes-DA-Silva M. \& CASAgrande M.M. 2003: Color polymorphism and allele frequency in a Brazilian population of the sunflower Caterpillar Chlosyne lacinia saundersi (Doubleday) (Lepidoptera: Nymphalidae). Neotrop. Entomol. 32: 159-161.

MAdDIsON W.P. \& MAdDISON D.R. 2010: Mesquite: A Modular System for Evolutionary Analysis. Version $2.73 \mathrm{http}: / /$ mesquiteproject.org

McBride C.S., van Velzen R. \& Larsen T.B. 2009: Allopatric origin of cryptic butterfly species that were discovered feeding on distinct host plants in sympatry. Mol. Ecol. 18: 3639-3651.

McLeod D.S. 2010: Of least concern? Systematics of a cryptic species complex: Limnonectes kuhlii (Amphibia; Anura: Dicroglossidae). Mol. Phylogen. Evol. 56: 991-1000.
Murray T.E., Fitzpatrick U., Brown M.J.F. \& Paxton R.J. 2008: Cryptic species diversity in a widespread bumble bee complex revealed using mitochondrial DNA RFLPs. Conserv. Genet. 9: 653-666.

Neck R.W., Bush G. \& Drummond B.A. III. 1971: Epistasis, associated with lethals and brood effect in larval colour polymorphism of the patch butterfly Chlosyne lacinia saundersi Geyer. Heredity 26: 73-84.

NECK R.W. 1973: Food plant ecology of the butterfly Chlosyne lacinia (Nymphalidae) I. Larval food plants. J. Lepid. Soc. 27: 22-33.

Nymphalidae Systematics Group 2009: The NSG's voucher specimen database of Nymphalidae butterflies. Version 1.0.15. http://nymphalidae.utu.fi/db.php

Posada D. 2008: jModelTest: Phylogenetic Model Averaging. Mol. Biol. Evol. 25: 1253-1256.

Ronquist F. \& HuelsenBECK J.P. 2003: Mr Bayes 3: Bayesian phylogenetic inference under mixed models. Bioinformatics 19: $1572-1574$

Schönrogge K., Barr B., Wardlaw J.C., Napper E., Gardner M.G., Breen J., Elmes G.W. \& Thomas J.A. 2002: When rare species become endangered: cryptic speciation in myrmecophilous hoverflies. Biol. J. Linn. Soc. 75: 291-300.

Scotт J.A. 1986: The Butterflies of North America: A Natural History and Field Guide. Stanford University Press, Stanford, CA, $583 \mathrm{pp}$

SмIтн M.A. 2006: DNA barcode reveal cryptic host-specificity within the presumed polyphagous members of a genus of parasitoid flies (Diptera: Tachinidae) PNAS 103: 3657-3662.

Sмith M.A., Wood D.M., Janzen D.H., Hallwachs W. \& HeBERT P.D.N. 2007: DNA barcodes affirm that 16 species of apparently generalist tropical parasitoid flies (Diptera, Tachinidae) are not all generalists. PNAS 104: 4967-4972.

SpERLING F.A.H. 2003: Butterfly molecular systematics. In Boggs C.L., Watt W.B. \& Ehrlich P.R. (eds): Butterflies: Ecology and Evolution Taking Flight. University of Chicago Press, Chicago, pp. 431-458.

Stewart B., Brodkin P. \& Brodkin H. 2001. Butterflies of Arizona: A Photographic Guide. West Coast Lady Press, Arcata, $\mathrm{CA}, \mathrm{ii}+415 \mathrm{pp}$.

Stuart B.L., Inger R.F. \& Voris H.K. 2006: High level of cryptic species diversity revealed by sympatric lineages of Southeast Asian forest frogs. Biol. Lett. 2: 470-474.

Wahlberg N. \& Zimmermann M. 2000: Pattern of phylogenetic relationships among members of the tribe Melitaeini (Lepidoptera: Nymphalidae) inferred from mtDNA sequences. Cladistics 16: 347-363.

WheAT C. \& WatT W. 2008: A mitochondrial-DNA-based phylogeny for some evolutionary-genetic model species of Colias butterflies (Lepidoptera, Pieridae). Mol. Phylogen. Evol. 47: 893-902.

Received March 22, 2011; revised and accepted August 4, 2011 